\title{
Excreção e transmissão do vírus da diarréia viral bovina por bezerros persistentemente infectados ${ }^{1}$
}

\author{
Sandra Arenhart ${ }^{2}$, Fernando V. Bauermann², Stephan A.M. Oliveira² ${ }^{2}$, Rudi \\ Weiblen $^{2}$ e Eduardo Furtado Flores ${ }^{2}$
}

\begin{abstract}
Arenhart S., Bauermann F.V., Oliveira S.A.M., Weiblen R. \& Flores E.F. 2009. [Shedding and transmission of bovine viral diarrhea virus by persistently infected calves.] Excreção e transmissão do vírus da diarréia viral bovina por bezerros persistentemente infectados. Pesquisa Veterinária Brasileira 29(9):736-742. Departamento de Medicina Veterinária Preventiva, Centro de Ciências Rurais, Universidade Federal de Santa Maria, 97105-900 Santa Maria, RS, Brazil. E-mail: eduardofurtadoflores@ gmail.com

Persistently infected $(\mathrm{PI})$ calves born to cows infected with non-cytopathic bovine virus diarrhea virus (BVDV) represent the main reservoir of the virus in nature. We herein report an investigation on the patterns of virus shedding and transmission by five $\mathrm{PI}$ calves produced experimentally through inoculation of pregnant cows with Brazilian BVDV isolates. Five calves that survived intrauterine infection were born healthy, lacking neutralizing antibodies to BVDV and harboring virus in the blood. After weaning - and following the disappearance of colostral antibodies - PI calves were monitored for virus in serum and body secretions (ocular, oral, nasal and genital) at weekly intervals for up to 150 days. For each animal, the virus titers in serum showed minor variations throughout the collections (with one exception that presented an increase late in infection), yet the titers varied widely among animals (from $10^{2}$ to $10^{6} \mathrm{TCID}_{50} / \mathrm{mL}$ ). Virus shedding in secretions was detected steadily during all the observation period with minor titer variations for each particular animal. The highest titers were generally detected in nasal and ocular secretions (titers $10^{4}$ to $10^{6} \mathrm{TCID}_{50} \mathrm{~mL}$ ) whereas genital and oral secretions usually contained low amount of virus $\left(10^{2}\right.$ to $\left.10^{3} T C I D_{50} \mathrm{~mL}\right)$. To evaluate the kinetics of virus transmission by these animals, one PI was introduced on a group of 10 seronegative calves maintained with a high animal density simulating the conditions of an intensive management. All 10 contact calves seroconverted to BVDV by day 30 . Another PI calf was introduced into a 48-head herd kept under a low animal density, extensive grass management. Among these animals, $8 / 48$ (16.6\%) seroconverted by day $10,26 / 48(54.1 \%)$ by day 40 and $37 / 48(77 \%)$ were seropositive at day 100 , when the monitoring was discontinued. These results show that continuous viremia and virus shedding in high titers in secretions by PI animals assure an efficient and rapid virus transmission to contact animals, being the kinetics of transmission much faster under intensive conditions.

INDEX TERMS: Bovine viral diarrhea virus, BVDV, persistent infection, transmission.
\end{abstract}

RESUMO.- Bezerros persistentemente infectados (PI) nascidos de vacas infectadas com amostras não-citopáticas do vírus da diarréia viral bovina (BVDV) se constituem nos

\footnotetext{
${ }^{1}$ Recebido em 20 de abril de 2009.

Aceito para publicação em 26 de maio de 2009.

Parte da Tese de Doutorado da primeira autora, no Programa de Pós-Graduação em Medicina Veterinária, Universidade Federal de Santa Maria (UFSM).

2 Setor de Virologia, Departamento de Medicina Veterinária Preventiva, UFSM, Santa Maria, RS 97105-900, Brasil. *Autor para correspondência: eduardofurtadoflores@gmail.com
}

principais reservatórios do vírus na natureza. Este trabaIho relata uma investigação do padrão de excreção e transmissão viral por cinco bezerros PI produzidos experimentalmente pela inoculação de vacas prenhes com isolados brasileiros do BVDV. Cinco bezerros que sobreviveram a infecção intrauterina nasceram saudáveis, soronegativos e com a presença de vírus no sangue. Após o desmame e desaparecimento dos anticorpos colostrais - os bezerros $\mathrm{PI}$ foram monitorados semanalmente durante 150 dias para a presença de vírus e títulos virais no soro e em secreções (ocular, oral, nasal e genital). Os títulos virais no soro de 
cada animal apresentaram pequenas variações durante 0 período (com exceção de um animal que apresentou um aumento de título tardiamente), mas os títulos variaram amplamente entre os animais (entre $10^{2}$ e $10^{6} \mathrm{TCID}_{50} / \mathrm{ml}$ ). $O$ vírus também foi excretado continuamente nas secreções de todos os animais, com pequenas variações de título entre as coletas. Os maiores títulos virais foram geralmente detectados nas secreções nasais e oculares (títulos de $10^{4}$ a $10^{6} \mathrm{TCID}_{50} / \mathrm{mL}$ ), enquanto as secreções orais e genitais usualmente continham títulos virais baixos $\left(10^{2} \mathrm{a}\right.$ $\left.10^{3} \mathrm{TCID}_{50 /} \mathrm{mL}\right)$. Com o objetivo de avaliar a dinâmica de transmissão viral, um bezerro PI foi introduzido em um grupo de 10 bezerros soronegativos, mantido com uma alta densidade animal e submetido a manejo diário para simular as condições de manejo semi-intensivo. Após 30 dias de convívio com o bezerro $\mathrm{PI}$, todos os demais animais haviam soroconvertido ao BVDV. Para investigar a transmissão viral sob condições extensivas, outro bezerro PI foi incorporado a um rebanho de 48 animais mantido a campo, com baixa densidade animal e submetido a manejo extensivo. Dentre estes animais, $8 / 48(16,6 \%)$ foram soropositivos para anticorpos no dia 10, 26/48 (54,1\%) no dia 40 e $37 / 48(77 \%)$ haviam soroconvertido no dia 100 , quando encerrou-se o monitoramento. Estes resultados demonstram que a viremia e excreção viral contínua em altos títulos por animais $\mathrm{PI}$ assegura a transmissão rápida do BVDV a animais mantidos em contato, sendo a transmissão notadamente mais rápida em condições intensivas e de alta densidade animal.

TERMOS DE INDEXAÇÃO: Vírus da diarréia viral bovina, BVDV, infecção persistente, transmissão.

\section{INTRODUÇÃO}

O vírus da diarréia viral bovina (Bovine viral diarrhea virus, BVDV) é um dos patógenos mais importantes de bovinos, responsável por perdas econômicas para a pecuária bovina em todo mundo (Baker 1995). O BVDV é um vírus envelopado, com $45 \mathrm{~nm}$ de diâmetro, genoma RNA de fita simples com $12,5 \mathrm{~kb}$, classificado na família Flaviviridae, gênero Pestivirus (Francki et al. 1991). Os pestivírus podem ser classificados em citopáticos (CP) e não-citopáticos (NCP), de acordo com o efeito da replicação viral em células de cultivo (Lindebach \& Rice 2001). A grande maioria dos isolados de campo pertencem ao biótipo NCP (Ridpath 2005).

A infecção de animais soronegativos pode produzir uma variedade de manifestações clínicas, que incluem infecções inaparentes, doença respiratória, digestiva, reprodutiva, a doença das mucosas (DM), síndrome hemorrágica (SH) e imunodepressão (Baker 1995). Fêmeas prenhes infectadas podem apresentar uma série de falhas reprodutivas como reabsorção embrionária, abortos, mumificações, malformações fetais, natimortalidade, nascimento de bezerros fracos e inviáveis (Grooms et al. 2007). A infecção fetal com amostras NCP entre os dias 45 e 125 de gestação freqüentemente resulta no nascimento de bezerros imunotolerantes e persistentemente infectados (PI) com o vírus (McClurkin et al. 1984). Os animais PI replicam e excretam o vírus durante toda a vida, constituindo-se no principal reservatório e fonte de disseminação viral entre os animais (Houe 1995). Pela sua importância epidemiológica, os animais PI se constituem nos principais alvos de programas de controle e erradicação do BVDV dos rebanhos (Brock et al. 1991, Houe 1995). O controle da infecção pelo BVDV baseia-se na identificação e eliminação dos animais PI, associados ou não com o uso de vacinas (Bolin 1995, Houe 1995). O objetivo maior da vacinação contra o BVDV em rebanhos de cria é a prevenção da infecção fetal e a conseqüente produção de bezerros PI (Bolin 1995).

A transmissão horizontal do BVDV ocorre por contato direto ou por contato indireto, com secreções contaminadas (Brock et al. 1991, Houe 1995). Durante a infecção aguda, geralmente a viremia e excreção viral são transitórias e em baixos títulos, mas mesmo assim podem resultar em transmissão viral (Thurmond 2005). Animais PI, ao contrário, excretam o vírus continuamente e em altos títulos nas secreções, o que assegura uma transmissão mais eficiente (Brock et al. 1991, Houe 1995). Além da transmissão horizontal, o BVDV é transmitido de forma eficiente através da placenta de fêmeas gestantes, resultando em infecção embrionária ou fetal com conseqüências diversas (Baker 1995).

Embora seja consenso de que os animais PI se constituem nos principais reservatórios e fontes de disseminação do BVDV nos rebanhos (Houe 1995), alguns aspectos da biologia da infecção persistente e de seu impacto na transmissão do vírus permanecem pouco conhecidos. Estudos para investigar a persistência e níveis do vírus no sangue ao longo do tempo, assim como os títulos virais excretados nas secreções por um longo período são raros na literatura (Brock et al. 1991). Da mesma forma, a maioria dos estudos de transmissão se baseia em observações naturais em condições estritamente específicas peculiares a rebanhos da América do Norte e países europeus (Barber et al. 1985, Martin \& Bohac 1986, Radostitis \& Littlejohns 1988, Moerman et al. 1993, Cherry et al. 1998, Rush et al. 2001). Em grande parte destes estudos, o número de animais $\mathrm{PI}$ presentes no rebanho, os títulos virais excretados por estes animais, o tempo real de contato e as condições e oportunidades de transmissão viral entre os animais não são controlados ou conhecidos.

Assim, o presente trabalho teve como objetivos investigar os níveis de viremia e excreção viral em secreções por cinco bezerros PI por um longo período (150 dias), além de monitorar a dinâmica de transmissão viral por dois destes animais sob condições de manejo intensivo e extensivo, simulando as condições epidemiológicas provavelmente encontradas em muitos rebanhos brasileiros.

\section{MATERIAL E MÉTODOS}

\section{Delineamento experimental}

Cinco bezerros persistentemente infectados $(\mathrm{PI})$ com o BVDV, produzidos pela inoculação de vacas prenhes com 
isolados brasileiros do vírus, foram monitorados durante 150 dias a partir do desmame. Durante este período, amostras de soro e secreções (nasais, oculares, orais e genitais) foram coletadas a diferentes intervalos e submetidas a isolamento e quantificação de vírus. Para avaliar a dinâmica de transmissão viral por estes animais, um bezerro PI foi incorporado a um grupo de bezerros mantido sob condições semi-intensivas e outro foi introduzido num rebanho criado sob condições extensivas. Os animais mantidos em contato com os bezerros PI foram submetidos a testes sorológicos a diferentes intervalos para se investigar a dinâmica de transmissão viral.

\section{Células e vírus}

Os procedimentos de isolamento e quantificação de vírus; e os testes de soroneutralização (SN) foram realizados em células de rim bovino MDBK (Madin Darby bovine kidney, American Type Culture Collection [ATCC] CCL-22) livres de pestivírus. As células foram cultivadas em meio essencial mínimo (MEM), contendo penicilina $\left(1,6 \mathrm{mg} \mathrm{mL}^{-1}\right)$, estreptomicina $\left(0,4 \mathrm{mg} \cdot \mathrm{mL}^{-1}\right)$ e fungizona $\left(25 \mathrm{mg} \cdot \mathrm{mL}^{-1}\right)$; suplementado com $10 \%$ de soro eqüino. A cepa padrão Singer do BVDV foi utilizada nos testes de SN. Os vírus utilizados para inocular as vacas prenhes e produzir os bezerros $\mathrm{PI}$ são isolados brasileiros de BVDV-1 (SV126.8 e UFSM-1) e BVDV-2 (SV63 e SV260).

\section{Bezerros PI}

Foram utilizados cinco bezerros PI produzidos pela inoculação de vacas prenhes com isolados brasileiros do BVDV entre os dias 30 e 90 de gestação (Arenhart et al. 2008). Os bezerros nasceram saudáveis e eram sorologicamente negativos para o BVDV ao nascer. Isolamento viral positivo logo após o nascimento e a diferentes intervalos após confirmou o caráter persistente da infecção (Arenhart et al. 2008). O monitoramento destes animais descrito no presente experimento foi realizado a partir do desmame, quando tinham 6-8 meses de idade. No início do experimento, os cinco animais eram positivos para vírus (isolamento positivo de capa flogística) e negativos para anticorpos.

\section{Monitoramento virológico dos bezerros PI}

Os bezerros PI foram monitorados durante 150 dias a partir do desmame, quando já não apresentavam anticorpos neutralizantes contra o BVDV no soro. Amostras de sangue para sorologia e de secreções corporais para detecção e quantificação de vírus foram inicialmente coletadas intervalos semanais e, posteriormente, no dia 150. Durante este período, os animais foram mantidos em um potreiro de pastagem nativa e foram suplementados com ração animal. Dois bezerros PI (\# 387 e 375) permaneceram 30 e 100 dias em rebanhos com manejo semiintensivo e extensivo, respectivamente, para se investigar a dinâmica de transmissão viral. Durante este período, soro e secreções corporais foram coletados conforme descrito acima.

\section{Isolamento e quantificação de vírus de soro e secreções}

As amostras de soro e de secreções corporais foram inicialmente submetidas a isolamento viral. Para isso, secreções nasais, oculares, orais e genitais foram coletadas com o auxílio de suabes de algodão e acondicionadas em $1 \mathrm{~mL}$ de MEM. Após agitação em vortex e drenagem, os tubos foram submetidos a centrifugação a baixa rotação (3.000xg por $10 \mathrm{~min})$. O sobrenadante $(0,2 \mathrm{~mL})$ foi então inoculado em tapetes de células MDBK cultivadas em placas de 24 cavidades. As amostras de soro $(0,2 \mathrm{~mL})$ foram inoculadas sem processamento prévio. Os cultivos inoculados foram monitorados por três passagens consecutivas de $72 \mathrm{~h}$ cada. Ao final da terceira passagem, as células inoculadas foram submetidas à imunofluorescência (IFA) para a detecção de antígenos virais, de acordo com metodologia descrita por Botton et al. (1998). As amostras positivas no isolamento viral foram posteriormente submetidas a quantificação do vírus, a partir das amostras originais, pelo método de diluição limitante, em células MDBK. Os títulos virais foram calculados de acordo com Reed \& Muench (1938) e estão expressos como $\log _{10} \mathrm{TCID}_{50 /} \mathrm{mL}$.

Transmissão do vírus sob condições intensivas e extensivas

A dinâmica de transmissão do BVDV pelos bezerros PI foi investigada em dois grupos de bezerros soronegativos mantidos sob condições de densidade animal e manejos diferentes. O primeiro grupo consistia de 10 bezerros que foram mantidos em uma área de campo nativo de aproximadamente dois hectares (ha). O bezerro PI \#387 foi introduzido no grupo no dia 0. Os animais foram mantidos a campo e diariamente eram reunidos em um curral, onde eram arraçoados em cochos coletivos e posteriormente (após aproximadamente $30 \mathrm{~min}$ ) retornavam ao pasto de origem. O manejo empregado objetivou simular condições de manejo encontradas em pequenas propriedades. Amostras de soro para sorologia foram coletadas no dia 0 (dia da introdução do animal PI), 15 e 30 dias após. O segundo grupo consistia de um rebanho de 48 bezerros de raças mistas, mantidos em uma área de campo nativo de aproximadamente 50 ha (lotação aproximada de 1 animal/ha). O bezerro PI \# 375 foi introduzido no grupo no dia 0. Estes animais foram mantidos em campo nativo, sem suplementação alimentar durante o período. Em intervalos de aproximadamente 30-40 dias, os animais eram reunidos em um curral com brete para procedimentos de rotina da propriedade (everminações, banhos carrapaticidas, etc.), quando coletavamse as amostras de sangue para a sorologia (coletas nos dias 0 , 15, 40, 70 e 100 após a introdução do bezerro PI).

\section{Sorologia}

As amostras de soro coletadas dos animais contato a diferentes intervalos após a introdução dos animais PI foram submetidas a testes de SN, de acordo com metodologia descrita por Botton et al. (1998). Cada amostra de soro foi testada em triplicata, em diluição de 1:5, frente a $100-200 \operatorname{TCID}_{50}$ da cepa padrão Singer, utilizando-se células MDBK como indicador da replicação viral. Amostras positivas e negativas foram utilizadas como controle nos testes de SN. A resposta sorológica foi avaliada nos dias 10, 15 e 30 nos animais criados sob condições intensivas e nos dias 15, 40, 70 e 100 naqueles mantidos sob condições extensivas.

\section{RESULTADOS}

\section{Os bezerros $\mathrm{PI}$}

Os bezerros utilizados neste trabalho nasceram de vacas inoculadas experimentalmente com um pool de isolados brasileiros do BVDV entre os dias 30 e 90 de gestação. Ao nascimento, os bezerros eram positivos para vírus e não possuíam anticorpos neutralizantes em níveis detectáveis pela SN (Arenhart et al. 2008). Trinta dias após o nascimento, todos os animais continuavam positivos para vírus, porém apresentavam títulos variáveis de anticorpos neutralizantes, provavelmente de origem colostral. Esses bezerros foram monitorados virologicamente (iso- 


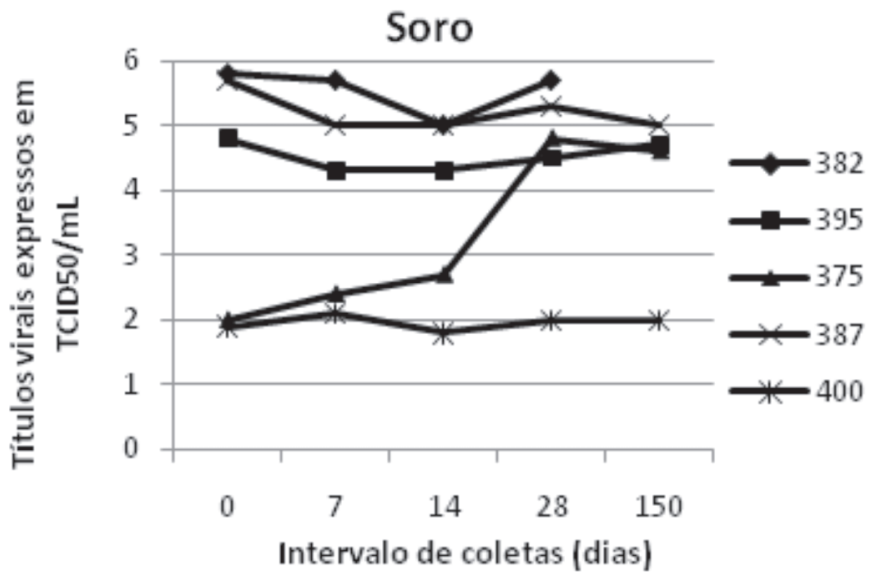

Fig.1. Títulos de vírus no soro de bezerros persistentemente infectados com o vírus da diarréia viral bovina (BVDV) a diferentes intervalos. $\mathrm{O}$ dia 0 (zero) corresponde ao primeiro dia de monitoramento, quando os animais tinham 6-8 meses de idade. O animal \#382 morreu no dia 40 de causas não relacionadas. Os títulos virais estão expressos em Log10.

Fig.2. Títulos de vírus em secreções de bezerros persistentemente infectados com o vírus da diarréia viral bovina (BVDV) a diferentes intervalos. $\mathrm{O}$ dia 0 (zero) corresponde ao primeiro dia de monitoramento, quando os animais tinham 6-8 meses de idade. $O$ animal \#382 morreu no dia 40 de causas não relacionadas. Os títulos virais estão expressos em Log10.
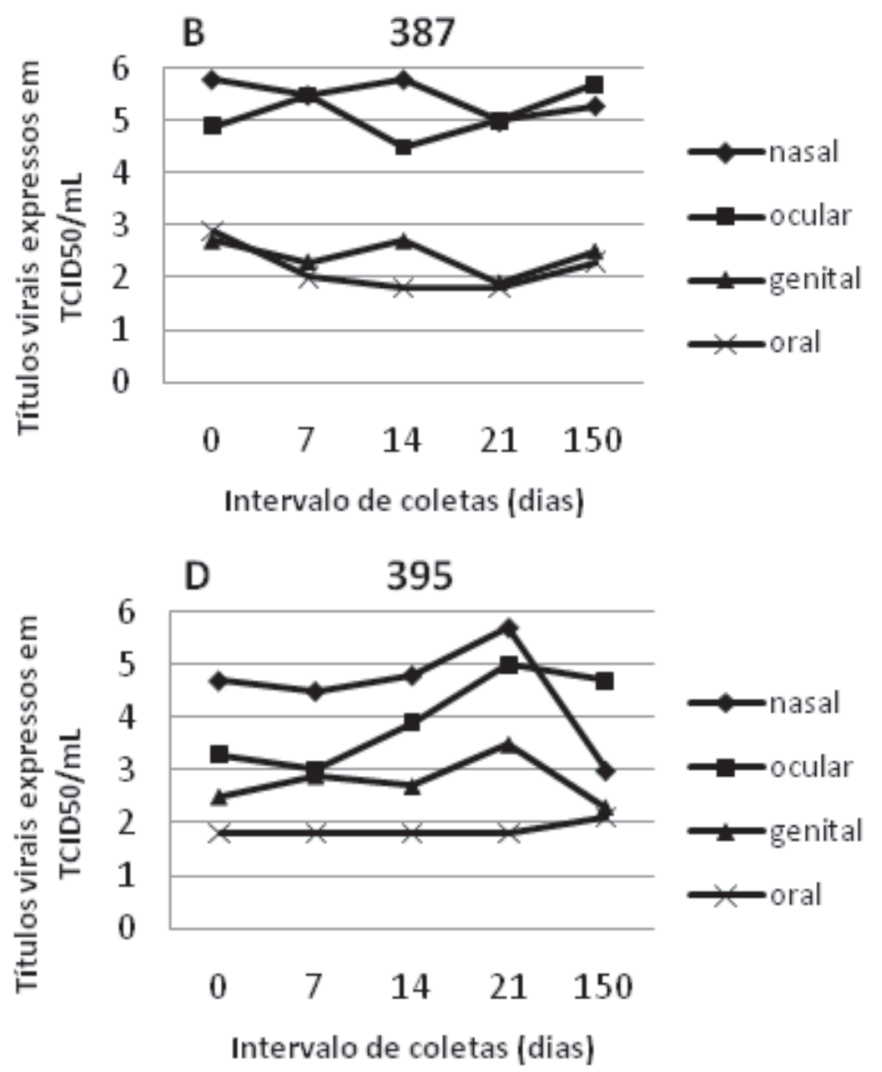

lamento viral) e sorologicamente (SN) a intervalos de aproximadamente 30 dias até o desmame (idade de 6-8 meses). Durante este período, foi possível isolar o vírus de leucócitos em todas as coletas, confirmando o caráter persistente da infecção. Os títulos de anticorpos neutralizantes foram se reduzindo gradativamente durante o período. Na ocasião do desmame e início do presente experimento todos os animais já haviam se tornado soronegativos ao BVDV (dados não mostrados). Um animal PI (\#382) morreu de causas não relacionadas aproximadamente 40 dias após o início do presente experimento.

\section{Presença de vírus no soro e em secreções}

Amostras de soro e de secreções corporais coletadas a intervalos semanais até o dia 28, e então no dia 150, foram submetidas a isolamento e quantificação de vírus.
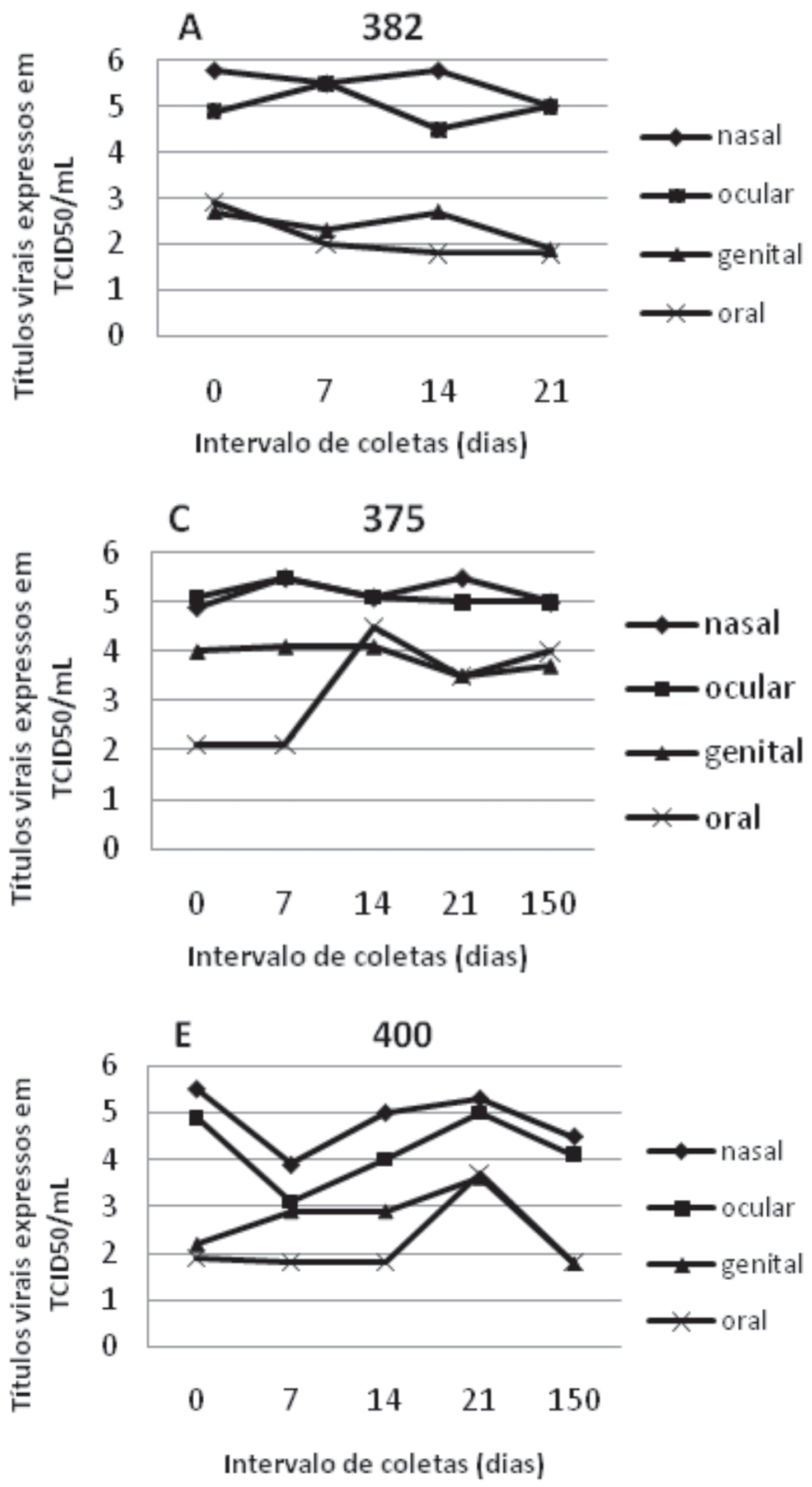

Pesq. Vet. Bras. 29(9):736-742, setembro 2009 
A evolução dos títulos de vírus no soro dos animais PI neste período está apresentada na Fig.1. Em quatro animais (\#382, 387, 395 e 400), os títulos apresentaram pequenas variações durante o período, embora se mantivessem em diferentes níveis. Dois animais apresentaram títulos persistentes iguais ou superiores a $10^{5} \mathrm{TCID}_{50} / \mathrm{mL}$, um entre $10^{4}$ e $10^{5} \mathrm{TCID}_{50} / \mathrm{mL}$, enquanto o animal \#400 apresentou títulos razoavelmente constantes ao redor $10^{2} \mathrm{TCID}_{50} / \mathrm{mL}$. O animal \#375 apresentou um aumento significativo de título entre as coletas dos dias 14 e 28, permanecendo com o vírus neste patamar até o dia 150 (entre $>10$ na 1.8 e 10 na 3 ).

A Figura 2 apresenta a evolução dos títulos virais nas secreções nasais, oculares, orais e genitais durante 0 período de monitoramento. Em geral, os títulos virais nas respectivas secreções de um mesmo animal não apresentaram grandes variações ao longo do período, com algumas exceções (ex: secreções orais nos animais \# 375 e 400; secreção ocular no animal \#395). Nos cinco animais, as secreções nasais e oculares continham os maiores títulos, atingindo valores entre $10^{4.5}$ e $10^{6} \mathrm{TCID}_{50} / \mathrm{mL}$ em quatro deles. Por outro lado, as secreções genitais e orais apresentaram os menores títulos (entre $10^{2} \mathrm{e}$ $10^{3} \mathrm{TCID}_{50}$ em quatro animais). Ao exemplo do que se observou com os títulos virais no soro, o animal \#375 apresentou aumento do título viral na secreção oral (entre a segunda e terceira coleta), e o animal \#395 apresentou aumento de vírus excretado na secreção ocular.

\section{Transmissão do vírus pelos animais $\mathbf{P I}$}

Com o objetivo de se avaliar a dinâmica de transmissão do vírus a partir dos animais $\mathrm{PI}$, dois destes bezerros (\#387 e 375) foram introduzidos em grupos de bovinos mantidos sob diferentes densidades e condições de manejo. No grupo mantido sob alta densidade (5 animais/ ha) e submetido a arraçoamento e manejo diário em um curral para simular condições de manejo de pequenas propriedades, o vírus foi transmitido com grande rapidez. Após 30 dias de convívio, os 10 animais contato já apresentavam anticorpos contra o BVDV (Quadro 1). No re-

Quadro 1. Soroconversão ao vírus da diarréia viral bovina (BVDV) por bezerros submetidos ao contato com bezer-

ros persistentemente infectados com o BVDV, sob condições extensivas ou semi-intensivas

\begin{tabular}{ccccccc}
\hline \multicolumn{3}{c}{ Criação extensiva $^{\mathrm{a}}$} & & \multicolumn{3}{c}{ Criação semi-intensiva } \\
\cline { 1 - 2 } \cline { 5 - 6 } Dia & Soropositivos & $\%$ & & Dia & Soropositivos & $\%$ \\
\hline 0 & $0 / 48$ & 0 & & 0 & $0 / 10$ & 0 \\
10 & $8 / 48$ & 16.6 & & 15 & $3 / 10$ & 30 \\
40 & $26 / 48$ & 54.1 & & 30 & $10 / 10$ & 100 \\
70 & $29 / 48$ & 60.4 & & & & \\
100 & $37 / 48$ & 77.0 & & &
\end{tabular}

a Densidade de aproximadamente 1 animal por hectare, mantidos a campo e manejados uma vez por mês em um curral com brete para simular manejo extensivo. Contato: bezerro PI 387.

b Densidade de aproximadamente 5 animais por hectare, arraçoados e manejados diariamente em um curral para simular manejo semi-intensivo. Contato: bezerro PI 375 banho mantido sob condições extensivas de manejo e baixa densidade animal, simulando condições de pecuária extensiva, a transmissão do vírus foi mais lenta e gradativa. Não obstante, ao final do monitoramento (dia 100) $77 \%$ dos animais já haviam soroconvertido ao BVDV (Quadro 1).

\section{DISCUSSÃO}

Os resultados demonstram que os bezerros $\mathrm{PI}$ apresentaram viremia persistente em títulos medianos a altos, pouco variáveis no mesmo animal, mas com grande variação entre animais durante o período de monitoramento. $O$ vírus também foi detectado continuamente, e com pequenas variações entre as coletas, nas secreções corporais coletadas a diferentes intervalos. As secreções nasais e oculares geralmente continham a maior quantidade de vírus. A anexação de um bezerro PI a um grupo de bovinos mantido sob condições semi-intensivas foi seguida de rápida transmissão viral, resultando em soroconversão de todos os animais aos 30 dias. A introdução de outro bezerro PI a um grupo de bovinos mantidos sob manejo extensivo também foi seguida da disseminação do vírus, porém com menor dinâmica. Estes resultados demonstram que a viremia persistente nos animais PI é acompanhada de excreção viral contínua em secreções corporais, o que resulta em transmissão rápida e eficiente a animais mantidos em contato.

É geralmente aceito que bezerros $\mathrm{Pl}$ excretam grandes quantidades de vírus nas secreções e excreções, mas informações sobre a duração (contínua x intermitente) e sobre os títulos virais excretados nas secreções são raros na literatura (Brock et al. 1991, Thurmond 2005). Os títulos virais em animais $\mathrm{PI}$ soronegativos podem atingir a $10^{6} \mathrm{TCID}_{50} / \mathrm{mL}$ no soro e no muco vaginal, $10^{5}$ no fluido uterino e $10^{4}$ na urina e fezes (Brock et al. 1991). Ao longo do tempo (<2 anos), os níveis de viremia em alguns $\mathrm{PI}$ podem apresentar uma queda de até $1 \log _{10} \mathrm{TCID}_{50} / \mathrm{mL}$ (Brock et al. 1998). Embora a transmissão direta pareça ser mais freqüente, os altos títulos presentes nas secreções podem também assegurar transmissão indireta (Brock et al. 1991, Houe 1995). A presença de anticorpos - mesmo indetectáveis pela SN - que apresentem reação cruzada contra o vírus residente pode resultar em redução (ou cessação) temporária da viremia e, conseqüentemente, da quantidade de vírus presente nas secreções (Howard et al. 1989, Brock et al. 1998). A existência de animais $\mathrm{PI}$ que podem permanecer indetectáveis, devido à excreção viral intermitente ou em baixos níveis, também tem sido relatada (Barber et al. 1985, Voges et al. 1998). Em especial, a excreção viral intermitente por alguns animais PI tem merecido atenção, pois pode dificultar a sua detecção e, conseqüentemente, a aplicação de medidas de controle (Brock et al. 1998, Thurmond 2005). No presente experimento, todos os animais PI apresentaram viremia persistente, em níveis pouco variáveis ao longo do tempo. O animal \#395 apresentou um aumento do título viral no soro, entre os dias 14 e 28 , acompanhado 
também do aumento do título viral na secreção oral (Fig.1 e 2C). Um aspecto importante observado foi a ampla variação dos níveis (ou títulos) de viremia entre os animais, achado já descrito por Brock et al. (1998). Essa variação pode ser devida a fatores individuais, mas também pode estar associada com a identidade do vírus residente. No presente experimento, as vacas mães dos bezerros foram inoculadas com um pool de isolados de BVDV e, até a elaboração deste trabalho, não havia sido possível se identificar inequivocamente o (s) vírus persistente (s) em cada bezerro PI (Arenhart S., não publicado). De qualquer forma, foi demonstrado que os bezerros $\mathrm{PI}$ apresentaram viremia persistente, em níveis moderados a altos, durante todo o período de observação. Do ponto de vista diagnóstico, estes animais aparentemente não representariam problema, pois seriam prontamente identificados por isolamento viral a partir do soro ou de leucócitos. Do ponto de vista epidemiológico, no entanto, certamente seriam importantes pela viremia e excreção viral persistente em títulos médios a altos.

Vários estudos foram realizados para investigar a dinâmica de disseminação do BVDV por animais PI nos Estados Unidos e em países europeus, sob uma variedade de condições de densidade animal, manejo e tipo de exploração (Barber et al. 1985, Martin \& Bohac 1986, Radostitis \& Littlejohns 1988, Moerman et al. 1993, Cherry et al. 1998, Rush et al. 2001). Em alguns destes, a densidade animal chegava a aproximadamente 10 animais/ $100 \mathrm{~m}^{2}$, quando altas taxas de transmissão foram observadas (Rush et al. 2001). Em contraste, transmissão relativamente lenta foi observada em propriedades de criação extensiva (Cherry et al. 1998). A maioria destes trabalhos foi realizada em condições específicas peculiares a rebanhos destes países, sobretudo feedlots, rebanhos de cria e recria de bezerras de raças leiteiras, propriedades especializadas no manejo de vacas secas e propriedades de exploração leiteira (Martin \& Bohac 1986, Michel et al. 1993, Taylor et al. 1995, Cherry et al. 1998). Além disso, em parte destes estudos o número de animais PI presente no rebanho, os títulos virais excretados por estes animais, as condições e oportunidades de transmissão viral entre os animais não eram conhecidos (Thurmond 2005). Assim, parte das observações sobre a transmissão do BVDV em condições naturais descritas na literatura pode não ser necessariamente aplicável às condições existentes em rebanhos brasileiros.

Em geral, considera-se que a velocidade de disseminação do vírus no rebanho dependa principalmente da prevalência de animais $\mathrm{PI}$, da freqüência de contato entre os animais, da virulência do vírus circulante e do percentual de animais susceptíveis (Thurmond 2005, Houe 1995). Pouco tem sido abordado sobre os títulos excretados e sobre o caráter (intermitente $x$ contínua). $O$ presente estudo demonstra que os animais $\mathrm{PI}$ excretaram o vírus continuamente, mas que os títulos excretados podem variar amplamente entre animais PI. Assim, é provável que os títulos virais excretados por determinado animal PI tam- bém influenciem a velocidade de disseminação no rebanho. Da mesma forma, animais que excretem o vírus de forma contínua - como observado no presente estudo seriam determinantes para uma rápida difusão do vírus.

Em rebanhos extensivos, em grandes áreas, baixa densidade animal e na ausência de animais PI no rebanho adulto (infecção mantida apenas por infecções agudas seqüenciais), a transmissão é geralmente lenta e pode levar até 2-3 anos para atingir a totalidade dos animais adultos (Barber et al. 1985, Moerman et al. 1993). Em dois rebanhos extensivos mantidos sob condições similares entre si $(0,7$ animal/ha) a presença de animais $\mathrm{PI}$ resultou numa velocidade de transmissão 10 vezes superior àquela proporcionada por animais com a infecção aguda (Cherry et al. 1998). Em outro estudo sob condições extensivas e baixa densidade animal, transmissão a partir de animais com a infecção aguda não foi observada, enquanto a presença de animal PI resultou em disseminação relativamente rápida (Radostitis \& Littlejohns 1988). Sob condições intensivas (feedlots, lotação de aprox. 10 animais $/ 100 \mathrm{~m}^{2}$ ) a transmissão a partir de animais $\mathrm{PI}$ foi muito rápida, com taxas de soroconversão entre 0,4 e $0,7 \%$ ao dia (Martin \& Bohac 1986). Um rebanho de novilhas leiteiras mantidas em condições semi-intensivas, e com a presença de uma bezerra PI, apresentou uma taxa de soroconversão de até $1,3 \%$ ao dia (Rush et al. 2001). No presente trabalho, a transmissão do vírus no rebanho mantido sob condições semi-intensivas (alta densidade, arraçoamento e manejo conjunto uma vez por dia) foi rápida, resultando em soroconversão de todos os animais até o dia 30. Em um estudo anterior sob condições similares, taxas de transmissão e soroconversão equivalentes já haviam sido observadas e 12 animais mantidos em contato com um bezerro PI soroconverteram em menos de 30 dias (Flores E.F., não publicado). As condições simuladas se assemelham àquelas encontradas em pequenos rebanhos leiteiros no RS, em termos de densidade e intensidade de manejo. Assim, pode-se especular que a introdução de um animal PI num rebanho com estas condições irá resultar numa rápida difusão viral e infecção da totalidade dos animais em um curto espaço de tempo. Por outro lado, a transmissão viral no rebanho extensivo foi mais lenta, embora tenha atingido $77 \%$ dos animais no período monitorado. Pela dinâmica de transmissão observada no período é provável que a totalidade dos animais já teria sido infectada ao final de 150-200 dias, caso o monitoramente tivesse prosseguido.

Em resumo, o presente estudo demonstrou que os bezerros PI apresentaram viremia contínua em níveis médios a altos ao longo do tempo. $O$ vírus também foi continuamente excretado em secreções, com os maiores títulos sendo detectados nas secreções nasais e oculares. A excreção viral pelo animal PI introduzido no grupo mantido sob manejo intensivo proporcionou uma rápida transmissão a todos os animais contato. Sob condições extensivas a transmissão foi mais lenta, mas atingiu grande parcela dos animais no período observado. Esses re- 
sultados podem contribuir para um melhor entendimento da biologia da infecção persistente e da epidemiologia da infecção pelo BVDV.

\section{REFERÊNCIAS}

Arenhart S., Silva L.F., Henzel A., Ferreira R., Weiblen R. \& Flores E.F. 2008. Proteção fetal contra o vírus da diarréia viral bovina (BVDV) em vacas prenhes previamente imunizadas com uma vacina experimental atenuada. Pesq. Vet. Bras. 28:461-470.

Baker J.C. 1995. The clinical manifestations of bovine viral diarrhea virus infection. Vet. Clin. North Am. 11:425-445.

Barber D.M.L., Nettleton P.F. \& Herring J.A. 1985. Disease in a dairy herd associated with the introduction and spread of bovine virus diarrhea virus. Vet.Rec. 117:459-464.

Bolin S. 1995. Control of bovine viral diarrhea virus infection by use of vaccination. Vet. Clin. North Am. 11:615-626.

Botton S.A., Silva A.M., Brum M.C.S., Flores E.F. \& Weiblen R. 1998. Antigenic characterization of Brazilian bovine viral diarrhea virus isolates by monoclonal antibodies and cross-neutralization. Braz. J. Med. Biol. Res. 31:1429-1438.

Brock K.V., Redman D.R., Vickers M.L., Irvine N.E. 1991. Quantitation of bovine viral diarrhea virus in embryo transfer flush fluids collected from a persistently infected heifer. J. Vet. Diagn. Invest. 3:99-100.

Brock K.V., Grooms D.L., Ridpath J.F. \& Bolin S.R. 1998. Changes in levels of viremia in cattle persistently infected with bovine viral diarrhea virus. J. Vet. Diagn. Invest. 10:22-26.

Cherry B.R., Reeves M.J. \& Smith G. 1998. Evaluation of bovine viral diarrhea virus control using a mathematical model of infection dynamics. Prev. Vet. Med. 33:91-108.

Dubovi E.J. 1992. Genetic diversity and BVD virus. Comp. Immun. Microbiol. Infect. Dis. 15:155-162.

Flores E.F., Weiblen R., Vogel F.S.F., Roehe P.M., Alfieri A.A. \& Pituco E.M. 2005. A infecção pelo vírus da Diarréia Viral Bovina (BVDV) no Brasil: histórico, situação atual e perspectivas. Pesq. Vet. Bras. 25:25-134.

Francki R.I.B., Fauquet C.M., Knudson D.L. \& Brown F. 1991. Classification and nomenclature of viruses. Fifth Report of the International Committee on the Taxonomy of Viruses. Arch. Virol. 2(Suppl.):228-229.

Grooms D.L., Bolin S.R., Coe P.H., Borges R.J. \& Coutu C.E. 2007. Fetal protection against exposure to bovine viral diarrhea virus following administration of a vaccine containing an inactivated bovine viral diarrhea virus fraction to cattle. Am. J. Vet. Res. 68:1417-1422.
Houe H. 1995. Epidemiology of bovine viral diarrhea virus. Vet. Clin. North Am. 11(3):521-548.

Howard C.J., Clarke M.C. \& Brownlie J. 1989. Protection against respiratory infection with bovine viral diarrhea virus by passively acquired antibodies. Vet. Microbiol. 19:195-203.

Lindenbach B.D. \& Rice C.M. 2001. Flaviviridae: The viruses and their replication, p.991-1042. In: Knipe D.M., Howley P.M., Griffin D.E (Eds), Fields Virology. Lippincot Williams and Williams, Philadelphia, PA.

Martin S.W. \& Bohac J.G. 1986. The association between serological titers in infectious bovine virus, bovine virus diarrhea virus, parainfluenza-3 virus, respiratory syncytial virus and treatment for respiratory disease in Ontario feedlot calves. Can. J. Vet. Res. 50:351358.

McClurkin A.W., Littledike E.T., Cutlip R.C., Frank G.H., Coria M.F. \& Bolin S.R. 1984. Production of cattle immunotolerant to BVD virus. Can. J. Comp. Med. 48:156-161.

Michel P., Thurmond M. \& Hietala S. 1993. Prevaccination bovine viral diarrhea virus titers and subsequent reproductive performance in dairy heifers. Can. J. Vet. Res. 57:236-240.

Moerman A., Strayer P.J. \& de Jong M.C.M. 1993. A long term epidemiological study of bovine viral diarrhea virus infections in a large herd of dairy cattle. Vet. Rec. 132:622-626.

Radostitis O.M. \& Littlejohns I.R. 1988. New concepts in the pathogenesis, diagnosis and control of diseases caused by bovine viral diarrhea virus. Can. J. Vet. Res. 29:513-528.

Reed L. \& Muench H. 1938. A simple method of estimating fifty percent endpoints. Am. J. Hyg. 18:493-494.

Ridpath J.F. 2005. Practical significance of heterogeneity among BVDV strains: Impact of biotype and genotype on U.S. control programs. Prev. Vet. Med. 72:17-30.

Rush D.M., Thurmond M.C., Muñoz-Sanzi C. \& Hietala S.K. 2001. Descriptive epidemiology of post-natal bovine viral diarrhea virus infection in intensively managed dairy heifers. J. Am. Vet. Med. Assoc. 219:1426-1431.

Taylor L.F., Van Donkersgoed J., Dubovi E.J. 1995. The prevalence of bovine viral diarrhea virus in a population of feedlot calves in western Canada. Can. J. Vet. Res. 59:87-93.

Thurmond M.C. 2005. Virus Transmission, p.91-104. In: Goyal S.M. \& Ridpath J.F. (Eds), Bovine Viral Diarrhea Virus: Diagnosis, management and control. Blackwell Publishing, Oxford, UK.

Voges H., Horner G.W., Rowe S. \& Wellenberg G.J. 1998. Persistent bovine pestivirus infection localized in the testes of an immunocompetent, non-viraemic bull. Vet. Microbiol. 61:165-175. 